\title{
Possibilities of using wheat bran for finishing pigs in the « Antilles »
}

\author{
J. LE IDIVIDICH *, I. CANOPE, F. HEDREVILLL, IE. IMIESPOIS \\ * Station de Recherche's sur l' lilevage des Porcs, I. N. R. A., C. N. R. Z., \\ 78350 Jouy en Josas \\ Station cxpérimentale de Zootechnie, I. N.R. A., C.R.A.A. G., \\ 97170 Petit-Bourg (Guadeloupo)
}

Two trials were made on a total of 82 pigs with the aim of studying the effect of incorporating high levels of wheat bran ( 15 to $90 \mathrm{p}$. 100 ) into the diets on the performances of the animals from $60 \mathrm{~kg}$ live weight.

Until an incorporation level of $45 \mathrm{p}$. Ioo, wheat bran had no marked influence either on growth rate of the animals or on feed conversion ratio. At the highest level ( $90 \mathrm{p}$. I0o), the growth rate decreased by $25 \mathrm{p}$. Ioo $(\mathrm{P}<0.05)$ and the feed conversion ratio increased by i 5 p. Ioo $(\mathrm{P}<0.05)$.

Increase in the level of bran in the diet caused a linear decrease in dressing percentage whereas backfat thickness decreased only a little.

It can be assumed that incorporation into the dict of wheat bran until a level of $45 \mathrm{p} .100$ has no unfavourable effect on the performances of finishing pigs.

\section{Study of some factors affecting feed efficiency when offering a cereal and a supplement separately}

\author{
J. LOUGNON, A.-M. GIRE \\ Société de Chimie Biologique, A.E.C., \\ o3600 Commentry
}

Two experiments were conducted to examine some factors liable to make feed efliciency vary when a cereal (maize) and a supplement (soyabean meal) were given separately.

The two trials were made on pigs (castrated males and females) of $2 \mathrm{I}$ to $\mathrm{r}$ oo $\mathrm{kg}$ to which a dict providing the same levels of energy and lysine was given every day.

When two complete diets were distributed every lay, lysine proved to be a soyabean meal sparing factor.

Performances (growth rate, feed conversion) and body composition decreased when a lownitrogen diet (cereal) and a high-nitrogen dict (oil-meal + minerals + vitamins) were offered separately.

Moreover, the respective times of feeding (morning or evening) did not have any effect. 
But when Iree lysine was added to the cereal, the performances (grow th rate, feed efficiency) were significantly higher $(+\& \mathrm{p}, 100)$ than those obtained in pigs when lysine was adeled to the oil-meal.

\title{
Eifect of dietary amino acid balance (lysine deliciency) and protein level on growing pig periormances
}

\author{
Y. HENRY, 1) BOTRI) \\ itation de Richerthe's sur l'Elerage des pores, I. N.R. I., C. N.R.Z. \\ 78.3.5\% Jouy in Josas
}

Three groups of 20 animals were kept in individual pens (between $2 \mathrm{f}$ and $100 \mathrm{~kg}$ live weight) in order to study the consequences of dietary protein reduction after amino acid supplementation, on growth performances and body composition of pigs under restricted feeding conditions and according to sex.

… (iroup BJ, lysine deficient (0.6 p. 100 up to $+5 \mathrm{~kg}$ live weight and $0 .+\mathrm{p}$. Ioo beyond that weight). but with a suitable protein supply (17.2 until $45 \mathrm{~kg}$, then 19.5 ).

.... (iroup HL, receiving a lysine supplementation, the total lysine contents being $0.80-0.05$ and $0.60 \mathrm{p}$. Ioo respectively before $+5 \mathrm{~kg}$, between 45 and $70 \mathrm{~kg}$ and after $70 \mathrm{~kg}$ live weight.

- Group BSN, recoiving a reduced supply of protein ( $3.5 \mathrm{P}$. Ioo up to $45 \mathrm{~kg}$ and $\mathrm{I} 2 \mathrm{p}$. Ion) beyond that weight), but suitably supplemented with essential amino acids.

The diets were composed of a mixture of cereals (barley, wheat and maize) providing it digestible energy value of 3 Ioo $\mathrm{kcal} / \mathrm{ks}$

The favourable influence of lysine supplementation showed that the reguirement was higher in the females than in the castrated males.

likewise, a difference between sexes was noted in the response to crude proten reluction, the requirements for e'sstntial amine acids being anvhow satisfid. In the case of castrated males subjected to usual feed restriction (progressive supply up to $2.7 \mathrm{~kg} / \mathrm{day}$ at $8 \mathrm{kog} \mathrm{kive}$ weight), the total requirement for crucle protein secmed to be satisfied by the levels: I + p. roo during the growing period and $12 \mathrm{p}$. 100 during the finishing periol (over $50 \mathrm{~kg}$ ), corresponding to +5 and fo g crucle protein/I ooo kcal digestible energy. This leals to a sparing of $15-20$ p. 1 so protein as compared to the recommended standards. However, in the females subjected to a more liberal feeding level (until $2.95 \mathrm{~kg} / \mathrm{day}$ ), the supply of crude protein must be maintained at a higher level, notably cluring early growth, to prevent excessive carcass adiposity. 